This is a so-called personal version (author's manuscript as accepted for publishing after the review process but prior to final layout and copy editing) of the article.

Raddats, C. and Kowalkowski, C. (2014), 'A re-conceptualization of manufacturers ' service strategies ', Journal of Business-to-Business Marketing, Vol. 21, Issue 1, pp. 19-34.

Readers are kindly asked to use the official publication in references.

\title{
A re-conceptualization of manufacturers' service strategies
}

Chris Raddats*, PhD, Lecturer in Marketing, University of Liverpool Management School, Chatham Street, Liverpool, L69 7ZH, United Kingdom.

(chrisr@liverpool.ac.uk), telephone: +44 1517953706

Christian Kowalkowski, PhD, Assistant Professor of Marketing, Department of Marketing, CERS - Centre for Relationship Marketing and Service Management, Hanken School of Economics, Helsinki, Arkadiagatan 22, 00101 Helsinki, Finland.

(christian.kowalkowski@hanken.fi), telephone: +358403521457

and

Associate Professor of Industrial Marketing, Department of Management and Engineering, Linköping University, 58183 Linköping, Sweden.

* Corresponding author

The authors would like to thank Professor Lars Witell (Linköping University) for his comments on an earlier version of this manuscript. 


\section{A re-conceptualization of manufacturers' service strategies}

\section{Structured Abstract}

\section{Purpose}

As part of 'service infusion', manufacturers use services to differentiate their products and provide growth. Although several attempts have been made to classify manufacturers' service strategies and offerings, most have been based on small purposive samples. The purpose of this article is to create a generic typology of manufacturers' service strategies.

\section{Methodology/approach}

The unit of analysis was the manufacturer or strategic business unit (SBU). The data collection was based on a survey of 145 business-to-business (B2B) manufacturers in the United Kingdom.

\section{Findings}

Three categories of service offerings were identified: product-attached services, operations services on own products and vendor independent operations services. These categories are used to specify three generic service strategies: Services Doubters, for whom services are not a strong differentiator with no focus on any category of service offerings; Services Pragmatists, for whom product-attached services are a key differentiator; Services Enthusiasts, for whom services are both a product differentiator and an enabler of growth, with all three categories of service offerings important.

\section{Research implications}

Whereas prior studies tend to use the concepts of service strategies and categories of service offerings interchangeably, we find empirical support for the importance of making a clear distinction between the two concepts.

\section{Practical implications}

Manufacturers can be classified according to their services strategies. For Services Doubters service infusion is unlikely to be an appropriate approach to creating differentiation. For Services Pragmatists services play a crucial role in creating product differentiation. Services Enthusiasts use services to both differentiate their own products and also develop services-led growth.

\section{Originality/value/contribution}

The paper exposes an ambiguity in the extant literature, with a manufacturer's categories of service offerings used as proxies for service strategies. A new typology of service strategies is presented based on categories of service offerings, which provides insight into how manufacturers infuse services.

Key words: B2B, manufacturer, service offerings, service infusion, servitization, strategy. 


\section{Introduction}

There has been an increasing focus in recent years on how business-to-business (B2B) manufacturers can infuse their products with services to develop more compelling customer offerings (Eggert et al. 2011; Paiola, Gebauer, and Edvardsson 2012; Ulaga and Reinartz 2011), with these approaches sometimes described as 'service infusion' (Kowalkowski et al. 2012) or 'servitization' (Vandermerwe and Rada 1988). As more research is conducted within this field it is becoming apparent that manufacturers seek competitive advantage through service infusion approaches which are based on diverse service strategies and offerings. Although some manufacturers' service offerings are under-developed (Lay et al. 2010) others have developed after-sales service offerings to enhance the reliability of their own products; for example, spares and repair, technical support, training (Gebauer 2007; Lele 1997). Other manufacturers' service infusion approaches are less focused on product reliability and more focused on revenue growth; for example, outsourcing services, whereby the risk and responsibility for customers' operational processes is assumed by the manufacturer (Gebauer 2008; Ulaga and Reinartz 2011). Some manufacturers are even developing solutions, which means that they sell combined product and service offerings to address important customer problems, and are compensated on the basis of achieved performance (Helander and Möller 2008; Nordin and Kowalkowski 2010; Storbacka 2011).

Articles which concern the service infusion phenomenon often discuss service strategies in terms of transitions (Ferreira et al. 2013; Mathieu 2001a; Matthyssens and Vandenbempt 2008; 2010; Oliva and Kallenberg 2003; Penttinen and Palmer 2007; Raddats and Easingwood 2010; Wise and Baumgartner 1999) or growth (Allmendinger and Lombreglia 2005; Auguste, Harmon, and Pandit 2006; Raddats 2011; Sawhney, Balasubramanium, and 
Krishnan 2004). Many studies use the concepts of service strategy and categories of service offerings more or less interchangeably (e.g., Lightfoot and Gebauer 2011; Matthyssens and Vandenbempt 2010; Penttinen and Palmer 2007; Raddats and Easingwood 2010; Stremersch, Wuyts, and Frambach 2001). As part of a service transition, manufacturers are urged to 'move' from one category of service offerings to a more infused one, eventually ending up offering the most infused category in the proposed framework (Mathieu 2001a; Matthyssens and Vandenbempt 2008; Oliva and Kallenberg 2003; Penttinen and Palmer 2007). Each distinct transition from a less to a more infused category of service offering is synonymous with a move between distinct service strategies; that is, category of service offerings is used as a proxy for service strategy. In reality, however, many manufacturers offer a wide range of services that do not fit neatly into only one category of service offerings within a typology; for example, offering standardized after-sales services as well as various product-independent services such as consultancy and integrated solutions (Kowalkowski, Kindström, and Brehmer 2011). Furthermore, many manufacturers also combine different service growth trajectories (Matthyssens and Vandenbempt 2010). Hence, it appears inaccurate to equate a manufacturer's service strategy with a particular category of service offerings. We therefore find confusion in existing frameworks/typologies between manufacturers' service strategies and categories of service offerings.

To provide greater clarity of this issue, we support calls for a more fine-grained assessment of manufacturers' industrial services (Eggert et al. 2011) and argue that current research does not fully address the complexities of the service infusion phenomenon. The objective of the study is therefore to create a service strategy typology which is appropriate for a wide crosssection of manufacturers. Through a study of 145 manufacturers we identify three distinct categories of service offerings which we use to specify three generic service strategies that 
manufacturers adopt. This study provides empirical support for making a clear distinction between the two concepts. It also goes some way to answering the call from Jacob and Ulaga (2008) for more large-scale cross-sectional studies in this area. Previous studies in this field have generally focused on case study research based on small samples (e.g., Salonen $2011-$ two companies; Kowalkowski et al. 2012 - one company). The exception to this is the study by Gebauer (2008) who also developed a typology after a large-scale survey.

The article is structured as follows: the theoretical context categorizes and discusses manufacturers' strategies, in particular those centred on services. The main service frameworks/typologies in the extant literature are presented together with the framework that provides the basis of the study. The research method, based on cluster analysis, is set out followed by the presentation of the results. The article continues with a discussion on the theoretical implications of the findings and limitations/further research areas. The implications of the study for business marketing practice are set out at the end of the paper.

\section{Theoretical context}

\subsection{Manufacturers' strategies}

Research into manufacturers' strategies typically focuses on the competitive capabilities required to achieve market differentiation. A number of competitive capabilities for manufacturers have been identified in the literature; for example, low price, design flexibility, volume flexibility, conformance (consistent quality), performance and after-sales service (Frambach, Wels-Lips, and Gundlach 1997; Frohlich and Dixon 2001; Miller and Roth 1994; Wouters 2004). According to Porter (1998) market differentiation comes from firms in the 
same industry having a different value chain, with sustainable competitive advantage (SCA) being potentially derived from each element of the value chain. One element capable of providing SCA is services; for example, customer support, training and product repairs (Porter 1998). Scholars have found that services are a competitive capability for manufacturers and are in many cases becoming of increasing strategic importance (Gebauer 2007; Grönroos 2000; Kowalkowski et al. 2012; Matthyssens and Vandenbempt 2010; Ulaga and Reinartz 2011).

In order to understand how manufacturers develop and manage services, a clearer distinction should be made between service strategy and category of service offerings. In order to elucidate this distinction, the concept of service strategy needs to be clarified and defined. Within the literature service strategies are related to specific business units rather than a corporation as a whole, since different business units within a company can have different service strategies (Govindarajan 1989). Thus, service strategy is a business-unit strategy rather than a corporate strategy, which applies to the whole enterprise. According to Andrews (1971), business strategy defines the choice of product/service offerings and markets of individual business units within a company. Based on this definition, we regard service strategy as the approach to defining categories of service offerings which a manufacturer will offer to a given market. The service strategy thus determines how the manufacturer competes with services in a given market to achieve differentiation. Whereas some manufacturers focus on services to create market differentiation; for others, services are less of a differentiating factor in their business strategy (Gebauer 2008). Consequently, we assume that service strategy can have very different roles within different manufacturers' overall business strategies.

\subsection{Frameworks/typologies of service strategies and categories of service offerings}


Growing attention from academics to service infusion within manufacturers over the last two decades has resulted in several frameworks and typologies that classify their service strategies and categories of service offerings. Mathieu (2001b) proposed a typology which includes 'customer service', 'product services' and 'services as products'. 'Customer service' is akin to the overall quality of service provided by a supplier as perceived by the customer (Parasuraman 1998). 'Product services' are supplementary offerings that B2B manufacturers are increasingly adding to their portfolios to enhance competitive differentiation and advantage; for example, installation, technical support, training (Parasuraman 1998). 'Services as products' are standalone entities, independent from the company's products; for example consultancy (Mathieu 2001b). Increasing levels of differentiation can be achieved by moving from customer service, through product services to services as products (Mathieu 2001b). Whereas some of these frameworks and typologies include all forms of services (Raddats and Easingwood 2010; Ulaga and Reinartz 2011) others focus specifically on extensive, process-oriented service offerings such as integrated solutions (Davies, Brady, and Hobday 2006). Solutions are however a rather vague concept (Nordin and Kowalkowski 2010) that are rarely defined and often used to describe a wide range of product/service bundles (Stremersch et al. 2001; Windahl and Lakemond 2010). Thus it is relevant to also include solutions-specific research in order to get a thorough understanding of the theoretical context of this study.

Mathieu (2001a) drew a distinction between service offerings closely linked to own products; for example, product installation (services supporting products or SSPs) and those that are more product-independent; for example, consultancy (services supporting customers or SSCs). The SSP-SSC dichotomy has been used to assess the impact of two different service 
infusion approaches (Antioco et al. 2008; Eggert et al. 2011; Salonen 2011). A variation on the SSP versus SSC dichotomy was set out by Auguste et al. (2006) with service infusion approaches categorised as 'defend' (akin to SSPs), whereby services are used to protect the traditional product business, or 'grow' (SSCs), whereby a distinct services business is developed, which can be independent from the traditional product business. The defend or grow distinction is apparent in other typologies of manufacturers' service infusion approaches; for example, Gebauer (2008) identified (among four categories) after-sales service providers (defend) and outsourcing partners (grow) whilst Raddats and Easingwood (2010) proposed (among four categories) product-attached services on own products (defend) and vendor agnostic operations services (grow). Whilst these typologies set out what are purportedly distinct strategies, in reality there is an acceptance that service infusions are complex, often requiring different and sometimes competing logics (Windahl and Lakemond 2010), which evolve through continuous modifications to address prevailing market conditions (Kowalkowski et al. 2012). For example, it could be argued that within Gebauer's (2008) typology, 'after-sales services' is a category of service offering, not a manufacturer's strategy. Equally, within Raddats and Easingwood's (2010) typology, 'product-attached services on own products' is a category of service offering, not a strategy.

A review of service infusion literature in academic and practitioner journals identifies a number of frameworks/typologies used to classify manufacturers' service strategies and categories of service offerings. Each of the frameworks/typologies has its own specific concepts, although there are major similarities between the key dimensions along which the concepts have been classified. Although some frameworks/typologies have no dimensions along which different categories of service offerings could be classified, seven specific dimensions were identified as being both frequent and fairly distinct. Each dimension is 
represented by two distinct categories to discriminate the service offerings, and these categories are listed below. For each of the seven dimensions, the second category of service offerings generally represents more infused, complex or extensive services.

1. Service supporting the supplier's product (SSPs) versus services supporting the customer's processes (SSCs) (Kowalkowski et al. 2011; Mathieu 2001a; Oliva and Kallenberg 2003; Raddats and Easingwood 2010; Ulaga and Reinartz 2011; Windahl and Lakemond 2010)

2. Transactional services versus relational services (Neely 2009; Oliva and Kallenberg 2003; Penttinen and Palmer 2007)

3. Individual services versus bundled and/or integrated services (Wise and Baumgartner 1999; Kowalkowski et al. 2011; Matthyssens and Vandenbempt 2008; Stremersch et al. 2001)

4. Standardized offering versus customized offering (Gebauer 2008; Lightfoot and Gebauer 2011; Matthyssens and Vandenbempt 2010; Penttinen and Palmer 2007; Stremersch et al. 2001)

5. Input-based services versus output-based services (Neely 2009; Raddats 2011; Ulaga and Reinartz 2011)

6. Product-attached services versus product-independent services (Auguste et al. 2006; Mathieu 2001b; Matthyssens and Vandenbempt 2010; Sawhney et al. 2004)

7. Services on own products versus services on multi-vendor products (Allmendinger and Lombreglia 2005; Davies et al. 2006; Raddats and Easingwood 2010).

Despite some differences, many of the first five dimensions are interrelated, which means that a transition from one category of service offerings to another most likely implies a 
change of category in another dimension as well. For example, increased customization is associated with increased technical integration and bundling of different services and of services and products (Kowalkowski et al. 2011; Matthyssens and Vandenbempt 2008). Increased customization and integration also changes the nature of the value proposition from input-based to output-based services (Neely 2009; Raddats 2011; Ulaga and Reinartz 2011).

Similarly, compared to SSPs, SSCs are associated with increased customization and a closer customer-supplier relationship (Mathieu 2001a). Close relationships are generally an antecedent/prerequisite for more extensive and complex services (e.g. customized, integrated, process-oriented, output-based offerings). Thus, closer relationships are needed for most service transitions (Kowalkowski et al. 2012; Mathieu 2001a; Oliva and Kallenberg 2003; Penttinen and Palmer 2007). However, the relevance of classifying service offerings according to the nature of customer-supplier relationship may be questionable, since the relationship is not a characteristic of a particular service category. For example, Otis, the world's leading manufacturer of elevators and escalators makes more than half its revenue from services, predominantly offering SSCs. The company has a 12-point roadmap for its employees to follow in order to practice service excellence, with this form of service thinking and practice implying a strong focus on the customer relationship. Equally, Linde, the leading industrial gas supplier, predominantly offers SSPs, and has achieved this strong market position by developing close relationships with its largest customers. Thus, a relational approach is practiced regardless of category of service offering. Companies can therefore pursue a relational strategy/approach even if they are only offering basic product-oriented services, and if their aim is to infuse more extensive and complex services such an approach may be the only viable option. Furthermore, in line with the basic premises of relationship marketing, service management and service-dominant logic, companies should have 
relational intent and a long-term relational orientation as a normative goal and therefore pursue a relational strategy whenever it is profitable (Copulsky and Wolf 1990; Grönroos and Helle 2010; Vargo and Lusch 2008).

The remaining two dimensions, "product-attached services versus product-independent services' and 'services on own products versus services on multi-vendor products' are interrelated and distinct from the first five as they have a clear and exclusive connection to the product offering. Manufacturers offering services primarily to protect or enhance the value of their product business (i.e. product-attached services) are generally reluctant to offer services on multi-vendor products (Auguste et al. 2006). On the other hand, manufacturers offering various product-independent services are more likely to offer services on multivendor products (Auguste et al. 2006; Raddats and Easingwood 2010). This distinction resembles Davies, Brady, and Hobday's (2007) comparison of a systems seller attaching services to its own products and a systems integrator that provides services which embrace multi-vendor products.

\subsection{Conceptual framework}

Most of the seven dimensions reviewed in the previous section are interrelated. As discussed, they might therefore be distilled to two distinct groups; one related to the first five dimensions of which the SSP-SSC dichotomy is the most common; the other related to the last two dimensions, with services associated with own or multi-vendor products. Among the reviewed frameworks/typologies, only the one proposed by Raddats and Easingwood (2010) includes both groups. The Raddats and Easingwood (2010) framework/typology is composed of the two dimensions: product/customer focus of services (SSP or SSC) and own products or 
own and third-party products, and includes four distinct categories of service offerings (Figure 1). It is generic and encompasses all types of service offerings, rather than just a subset of service offerings (e.g. integrated solutions). As previously contended, the two dimensions are fundamentally different; 'product/customer' concerns the role the services in the customer's business whereas 'own products/own and third-party products' has a clear connection to the product business, since the decision whether or not to offer services on third-party products is at the heart of the manufacturer's strategic decision-making. Furthermore, whereas many dimensions classify services on a continuum (e.g. from low to high degree of customization or integration) the two dimensions in Raddats and Easingwood's (2010) framework each have two distinct categories (i.e. SSP or SSC and services on own products or services on multi-vendor products).

\section{Figure 1 here}

As previously contended, a manufacturer's service strategy is based on the categories of service offerings (and ultimately services) it provides to its markets. Therefore, to address the research objective it was necessary to identify categories of service offerings which were applicable to a wide cross-section of manufacturers. A review of existing frameworks/typologies suggested that the one proposed by Raddats and Easingwood (2010) also addressed this requirement, since the empirical data on which it was based came from 25 manufacturers across 11 sectors.

\section{Methodology}


The objective of the study was to create a service strategy typology which is appropriate for a wide cross-section of manufacturers. Given the embryonic nature of this topic, the research strategy is therefore exploratory and inductive, meaning that the study aims to develop theory concerning manufacturers' service strategies (Bryman 2008). A cross-sectional (survey) design was used in this study, which is characterized by the collection of data from multiple cases at a single point in time. Data is quantifiable in connection with multiple variables, which can be examined in order to detect patterns of associations (Bryman 2008).

Although exploratory, inductive studies are often qualitative in nature, cluster analysis (a quantitative technique) was employed in this study. Cluster analysis is recognized as an inductive method of classification, widely used in marketing research for organizing observed data into meaningful taxonomies or segments based on the characteristics they possess (Field 2010; Hair et al. 2006; Punj and Stewart 1983). It is the most commonly used technique for this purpose (Hair et al. 2006); although it is acknowledged that alternative approaches to developing theory exist. Cluster analysis is preferred to qualitative methods because of the need to create a typology based on a large sample, to enable a wide range of manufacturing sectors to be included.

\subsection{Data sample and collection}

To achieve the research objective a probability sampling approach was used to reduce sampling error (Saunders, Lewis, and Thornhill 2007). The sampling frame was UK-based B2B manufacturers within standard industrial classification (SIC) 2003 categories 10 to 14 and 20 to 36 . The unit of analysis for the study was the company or strategic business unit (SBU) in larger companies, as it is possible that a company can have SBUs following 
different service strategies (Govindarajan 1989). Each company/SBU (hereinafter called company) had a minimum annual turnover of $£ 5$ million (equivalent to c. $50+$ employees, according to data from the FAME database, Bureau van Dijk). The selection of sample elements was performed using a list supplied by a reputable provider of B2B data (Market Location Ltd) in order to reduce coverage error (Saunders et al. 2007); that is, data from this list is regularly checked for accuracy through a complete re-fresh every 12 months. A stratified random sample (de Vaus 2002) was obtained comprising 642 companies, with the stratification designed, as far as possible, to ensure that a representative number of each SIC category was included in the survey. The minimum sample size was calculated based on a requirement to have a completed sample of at least 100 cases (in order to perform cluster analysis - Hair et al. 2006) and a likely response rate of around 25\% (Paxson [1992] estimates $25 \%$ as a good response rate from a B2B population). The data list detailed each company's marketing manager who was the key informant for the study. Each potential respondent was contacted to confirm that they were happy to take part in the research and to verify their knowledge of their company's service operations.

Data collection was by means of a self-completion questionnaire sent either by post or e-mail. Follow-up procedures to maximise the response rate involved firstly a postcard or e-mail, and secondly phone calls to the intended recipients of the letters/e-mails. It is important to maximise response rate to reduce non-response error and to confirm reasons for non-response (Chisnall 2005), with the telephone follow-up particularly effective at this (57 responses were received after telephone follow-up). An independent samples t-test was performed to ensure that survey responses received pre-telephone follow-up were similar to those received after telephone follow-up (Field 2010), which was the case. The sample was therefore treated as one group for subsequent analyses. Non-response appeared to be more due to lack of 
time/interest in the survey rather than a particular characteristic of non-responding companies or individuals. It was therefore felt safe to assume that non-respondents were similar to those who responded. In total 145 usable responses were received over a 6-month period, representing a response rate of $24 \%$.

\subsection{Item and survey development}

Items were developed which operationalized Raddats and Easingwood's (2010) four categories of service offerings, with the aim of achieving reliability and validity in the survey instrument (Fowler 2009). Items were designed to measure the latent variable underlying them (in this case, the category of service offering), with multiple items constituting a more reliable test, even though individual items should still be sensitive to the true score of the latent variable (de Vaus 2002). For this study, multiple items were developed for each category of service offering. As is common practice, the item development process involved two-stages; firstly, item generation and secondly, item refinement (Churchill 1979). Given that this is a new quantitative research topic, no pre-existing items were available. In this situation researchers are advised to discuss possible items with the groups to be surveyed to get an indication of which ones might be appropriate, in order to increase validity (de Vaus 2002). A pool of items was generated by the authors using their expertise and knowledge of prior research in this area, with four potential items developed on average for each one that was ultimately used. Potential items were refined through extensive and iterative discussions with 10 managers from the population to ensure that they not only reflected the underlying service category but were also unambiguous. Managers involved in this process were from different sectors of the population, in order to ensure consistent meaning of items across all respondents. Two academic experts in this field were asked to assess the face validity of the 
items in relation to the constructs (categories of service offerings), in order to assess the parsimony of the refined item pool (Churchill 1979).

The items ultimately chosen for use in the study are shown in Table 1, with an indication of the related 'category of service offering' (see 1-4 on Figure 1) and the rationale for each item. The first three service categories had three items each, although to enhance the parsimony of survey the second and third items (shown in Table 1) were each used for two service categories. This was possible as the items concerned services aligned to the supplied products, be they own product only (the first service category) or own and third party products (the second service category). The fourth service category had four items to capture the diverse range of service offerings which it encompasses.

The survey comprised items with seven-point Likert-type scales; 1 = 'strongly disagree', 7 = 'strongly agree' and $4=$ 'neither agree nor disagree', with unlabelled positions in between. There were also three other items in the survey (shown in Section 4.1) to help verify the proposed clusters using potentially discriminating variables not included in the cluster analysis (Hair et al. 2006). If a respondent could not respond to a particular item he/she was asked to note this at the end of the survey (DeVellis 2003).

\section{Table 1 here}

In order to reduce common method bias (Lindell and Whitney 2001), specifically overjustification, respondents were unaware of the relationship between the items and Raddats and Easingwood's (2010) typology. Careful consideration was also given to designing the survey instrument, both paper and online versions, with a requirement to avoid response bias 
attributable to the media used ('unimode construction', Dillman 2007). The survey was pretested with three members of the population who did not form part of the completed sample (Churchill and Iacobucci 2005). Comments from these reviewers helped to ensure that; 1) the Web-based survey was very similar in presentation to the paper-based version, 2) the survey was self-explanatory, 3) the items were ordered in a logical way and 4) the survey was not too long.

\subsection{Data analysis}

Cluster analysis was used to analyze the data with the aim of assigning each company to a suitable group based on its service strategy (Hair et al. 2006). Ketchen and Shook (1996) identified a number of criticisms of cluster analysis; primarily that group membership can be assigned even if no meaningful clusters exist. To help address this issue, Hair et al. (2006) stress the importance of a strong theoretical basis for undertaking the analysis to overcome this perceived weaknesses of the technique. The use of an established framework/typology to guide the research process was therefore important for this study.

Preliminary analysis of the data required an assessment of outliers and standardization of data (if required) (Hair et al. 2006). An initial check of univariate outliers was made to confirm that all responses were with within the 1-7 range, with a common response format for the variables meaning that the data did not need to be standardized. Hair et al. (2006) note two main assumptions for cluster analysis: firstly, the data is a representative sample of the population and secondly, multi-collinearity among variables in the cluster is minimal. To address the first assumption, Table 2 shows a comparison of the percentage of companies in each sector in the population (sourced through the FAME database, Bureau Van Dijk) versus 
the completed sample. This analysis shows that the population was particularly underrepresented in sectors $10-14,20-26$ and 34 and over-represented in sectors $29,30,32,33$ and 35. Despite discrepancies between the composition of the population and sample it was felt that the analysis should proceed because of difficulties in exactly mirroring the composition of the population from a self-selecting sample (Dillman [2007] notes the difficulties of collecting suitable data for B2B surveys).

\section{Table 2 here}

In terms of the second assumption, multi-collinearity was corrected through undertaking exploratory factor analysis (Ketchen and Shook 1996) and using uncorrelated factor scores as a basis for clustering. Items were therefore subjected to principle component analysis (PCA) with Varimax rotation (Hair et al. 2006). To confirm that the data set was suitable for factor analysis, the Kaiser-Meyer-Olkin (KMO) Measure of Sampling Adequacy was recorded as .77 and Barlett's Test of sphericity value was significant. There were many correlation coefficients above .3 in the Correlation Matrix, supporting the factorability of the data. The factor solution contained three distinct factors with eigenvalues above $1(3.55,1.91$ and 1.08$)$ accounting for $59.4 \%$ of the common variance, with Catell's (1966) scree test also supported the retention of three factors. The three factors can be interpreted as follows: firstly, 'Productattached services' - a category of services linked to either a manufacturer's own products and/or those of other OEMs; secondly, 'Operations services on own products' - a category of services concerned with activities on own products in the customer's operational environment; thirdly, 'Vendor independent operations services' - a category of services concerned with activities on own and/or other OEMs' products in the customer's operational 
environment. The reliability of the three scales was assessed and the results presented in Table 3, with Cronbach alpha values 'respectable' (DeVellis 2003).

\section{Table 3 here}

\section{Results}

\subsection{Cluster analysis}

Cluster analysis was performed on the basis of three distinct factors using a hierarchical cluster approach (Ward's method) to determine the optimum number of clusters in the sample. Hair et al. (2006) contend that this is one of the best methods when there are few outliers in the data. Cluster analysis was run initially with no specified number of clusters, which resulted in a dendrogram suggesting three distinct clusters. This was supported by measuring the heterogeneity among the agglomeration coefficients derived as part of the analysis (Hair et al. 2006). The analysis was re-run forcing a three-cluster solution to ensure that every case was grouped within a particular cluster. ANOVA tests associated with cluster analysis were performed to ascertain whether the factors significantly differentiate the three clusters (Table 4). This was confirmed with a significant result in each case.

\section{Table 4 here}

The cluster means for each discriminating factor are presented in Table 5. The maximum value for each factor is also provided to enable an appreciation of whether the mean scores are relatively high or low. The Tukey post-hoc test was used to determine where significant 
differences in the groups lie $(\mathrm{p}<.05)$ (Hair et al. 2006). For product attached services, significant group differences were found between clusters 1 and 2, and 2 and 3. For both operations services on own products and vendor independent operations services, significant group differences were found between clusters 1 and 2, and 1 and 3. Given that each cluster's membership differs significantly from the others, it is possible to use this grouping to describe cluster characteristics based on their service strategies.

\section{Table 5 here}

The proposed clusters were analysed using three potentially discriminating variables not included in the cluster analysis (Table 6). Each cluster was also assessed to determine which one was dominant. The first potentially discriminating variable was the percentage of corporate revenue from services, as it would be expected that a more servitized manufacturer would have a higher percentage of revenue from services in its corporate total (Fang et al. 2008; Gebauer et al. 2005). We measured the turnover from services in bands, which is a common approach among marketing researchers and used, for example, by Antioco et al. (2008). The survey item was coded as follows: less than 15\% turnover from services (1), 15 to $29 \%$ (2), 30 to $44 \%$ (3), 45 to $59 \%$ (4). It was assumed that no manufacturer had services revenue of $60 \%$ or above, and exact percentages were not recorded in the survey. Results showed that cluster 1 was dominant for this variable.

The second potentially discriminating variable was whether manufacturers believed their products provided strategic competitive advantage (SCA), since it might be expected that those manufacturers for whom products were a source of SCA would be less inclined to seek services growth, as products were already delivering strong sales and profitability. The item 
'Products provide my company with sustainable competitive advantage' was sourced from Griffin and Page (1993), with a response format similar to previous items in the survey. Results showed that cluster 3 was dominant for this variable.

The third potentially discriminating variable was how services are organized within a manufacturer's corporate structure, with manufacturers using services as a strategy for growth often, isolating their services from their products within the organization (Auguste et al. 2006; Oliva, Gebauer and Brann 2012; Oliva and Kallenberg 2003; Raddats and Burton 2011). The item 'Services are in a stand-alone business within my company's organization' was used in the survey, with a similar response format to other items in the survey. Results showed that cluster 1 was dominant for this variable.

\section{Table 6 here}

\subsection{Cluster descriptions}

Cluster 1- Services Enthusiasts

This pre-eminent cluster represents $45 \%$ of manufacturers and is characterized by a strong focus on all three categories of service offerings. This suggests that even when vendor independent operations services are important to a manufacturer, this does not mean that its focus shifts away from product-attached and operations services on its own products. As might be expected these manufacturers have above average revenue from services indicating that they have established service businesses, which are likely to be a standalone SBUs. In fact, Services Enthusiasts was the only cluster with turnover from services above the $20-30 \%$ 
threshold that Fang et al. (2008) found was required for achieving a higher firm value than manufacturers not selling any services at all. The results correspond to prior findings that manufacturers offering a broad range of services establish independent SBUs responsible for their service businesses (Gebauer and Kowalkowski 2012). Equally these companies appear less convinced than those in the other clusters that their products provide them with SCA, with services therefore helping to create differentiation and grow revenue. Manufacturers from the office machinery and computer sector (SIC code 30) were most represented in this cluster with $15.4 \%$ of the total.

\section{Cluster 2 - Services Doubters}

The smallest cluster representing $18 \%$ of manufacturers shows low focus on all three categories of service offerings. This indicates a group of manufacturers for whom services are not a strong differentiating factor, with their service businesses under-developed. This is supported by below average turnover from services and above average SCA from their products. Somewhat surprisingly services may be run from a standalone SBU (an above average score) which suggests that these manufacturers may have sought to isolate their service operations, but this has not been successful given the low focus on every category of service offerings. Although isolating the service operations is generally regarded as important to grow the service business, isolation per se is no guarantee for success (Gebauer and Kowalkowski 2012). It therefore appears that for these companies service opportunities may be limited, with differentiation likely to be sought through non-services factors. Manufacturers from the basic metals (SIC code 27) and machinery (SIC code 29) sectors were most represented in this cluster with $15.4 \%$ of the total each. 
A cluster representing $37 \%$ of manufacturers that is predominantly focused on productattached services, which are likely to be mainly related to own products and those of other OEMs to a limited extent. They achieve below average turnover from services but above average SCA from their products. This suggests that these companies use services to differentiate their own products, which corresponds to a traditional product-centric view of their businesses. From an organizational perspective services are closely linked with products, with below average likelihood of a standalone services SBU. Not separating product and service SBUs could be a deliberate choice given that manufacturers in this segment generally offer product-attached services. It could enable the companies to benefit from the strategic linkages between their product and service operations, which is vital for services directly attached to the companies' products (Baveja, Gilbert, and Ledingham 2004; Ulaga and Reinartz 2011). Manufacturers from the fabricated metal sector (SIC code 28) were most represented with $22.2 \%$ of the total.

\section{Discussion}

\subsection{Theoretical implications}

This paper has begun to classify the diverse range of frameworks and typologies that have been created to articulate the service infusion phenomenon, based on both service strategies and categories of service offerings. In doing so it makes a number of important contributions. Firstly, it has exposed an ambiguity in the extant literature, with categories of service offerings; for example, 'after-sales services' (Gebauer 2008) used as proxies for service 
strategies. This ambiguity means that these studies often fail to fully explore instances where a manufacturer's strategy is not specifically to provide services or to provide multiple categories of service offerings.

Secondly, the objective of the study was to create a service strategy typology which is appropriate for a wide cross-section of manufacturers. In answering Matthyssens and Vandenbempt's (2010) call to study the co-existence of different service types in one company, we therefore present a new typology of service strategies (see Figure 2). We believe that this new typology can unify much of the previous research in this area and offers an enhancement to the frameworks/typologies that have gone before. As contended, the typology does not confuse service strategies and categories of service offerings (cf. Gebauer 2008). It addresses a wide cross-section of the population, not specifically focussing on highly infused service businesses (cf. Davies et al. 2006). It is based on an existing and widely cited framework (Raddats and Easingwood 2010) that addresses the two key dimensions identified in the literature; the SSP or SSC dimension and the services attached to own or multi-vendor products dimension.

\section{Figure 2 here}

However, whereas Raddats and Easingwood (2010) identified four categories of service offerings, this study suggests that there are only three. The original categories of service offerings proposed by Raddats and Easingwood (2010) 'Product-attached services on own products' and 'Product-attached services on own and third party products' were found to be part of the same group. This is not surprising given that it is likely that many manufacturers which mainly supply, install and support their own products might also do the same for some 
other OEMs' products, if required by their customers (Mathieu 2001b). In this situation these categories are unlikely to form two statistically dissimilar groups. In Figure 2, 'High' or 'Low' indicates the likelihood that a manufacturer pursuing a particular service strategy is offering a particular category of service offerings. This sorting is based on the significant differences for the categories of service offerings between the service strategies.

The results in this study suggest that the three categories of service offerings identified in this research (Product-attached services, Operations services on own products, Vendor independent operations services) do not represent strategies per se. Only when considered in combinations they do; that is, Services Doubters, Services Pragmatists and Services Enthusiasts are groups of manufacturers undertaking distinct strategies. Some manufacturers can be described as Services Doubters which are not undertaking service infusion to any great extent, supporting Lay et al. (2010). This study suggests that some of these companies have set up independent service business units, although the implementation of the strategy might not have been successful (Gebauer, Fleisch, and Friedli 2005; Homburg, Fassnacht, and Guenther 2003), hence the lack of focus on any category of service offerings. Services Pragmatists provide services on their own products to enhance what they already perceive as differentiated products (a 'defend' strategy, Auguste et al. 2006), with services run from combined product/service business units (supporting Neu and Brown 2005). If the manufacturer's principal strategy is to defend and grow the product business, services are generally seen as add-ons, or even 'a necessary evil' (Kowalkowski et al. 2012; Robinson, Clarke-Hill, and Clarkson 2002) needed to ensure future product sales. Thus, the focus is on product-attached services on their own products as these services can be used to augment the traditional, core product offering. However, Services Pragmatists might also provide productattached services on other OEMs' products where this does not adversely affect sales of their 
own products, although this option is less common. Services Enthusiasts offer all three categories of service offerings and predominantly come from the office machinery and computer sector, supporting other studies which have emphasised the importance of service infusion for this group (Neu and Brown 2005). Manufacturers in this cluster have set up independent service business units, supporting finding from other studies (Gebauer and Kowalkowski 2012; Raddats and Burton 2011).

Thirdly, the idea of Services Enthusiasts offering SSPs/SSCs and services on own and third party products undermines the dichotomies set out by some scholars, who invariably chart a course for manufacturers towards more service-infused businesses though transitions between categories of service offerings (Mathieu 2001a; Matthyssens and Vandenbempt 2010; Oliva and Kallenberg 2003; Raddats and Easingwood 2010). Our research however shows that manufacturers infusing services may expand their offerings rather than move from one category to another, thereby supporting some prior longitudinal studies (Davies et al. 2006; Kowalkowski et al. 2012). In particular, we modify Anticio et al.'s (2008) criticism of SSPs and SSCs (it is difficult to delineate between them) and note that manufacturers (Services Enthusiasts) will probably offer both SSCs and SSPs at the same time, so a transition between them is not necessarily accurate.

\subsection{Limitations and further research}

There are a number of limitations associated with this research that need to be highlighted. To fully justify the external validity of the clusters it is recommended that cluster analysis is run on an alternative sample to cross-validate the findings (Hair et al. 2006). As has been previously noted an alternative sample is not always available (Ketchen and Shook 1996), 
although it would be beneficial to carry out this study on a second sample. Although every effort was made to use a sample representative of the population, in a B2B environment this is extremely difficult, and consequently certain sectors are over-represented and others underrepresented. The survey did not include negatively worded items, which some academics believe are necessary to reduce common method bias (de Vaus 2002), although others have argued to the contrary (Podsakoff et al. 2003; DeVellis 2003). The absence of pre-existing items meant that the majority of them had to be created through a pre-survey empirical study. Once again re-running this survey would provide a check on the reliability of the scales used. Finally, because many of the manufacturers in the survey do not report services revenue separately from that of products, we used a categorical measure to assess the percentage of total revenue from services, in case managers either did not know this figure exactly or would not be prepared to disclose it.

In terms of further research, we urge academics to further consolidate the disparate frameworks and typologies currently in existence. In particular the confusion surrounding service strategies and categories of service offerings needs to be addressed. We have made a start to this process but more needs to be done, for example the diverse definitions of solutions could be better categorized highlighting the key dimensions of each. Equally, further research is required to determine the veracity of frameworks showing clear transitions from one service category to another, with our research suggesting this is not how manufacturers infuse services. In this regard, we call for further quantitative research to test and verify existing frameworks. Finally, since existing studies of manufacturers' service strategies and offerings almost exclusively focus on large companies based in Western Europe and the US, further quantitative research should include data from other countries as well as both large manufacturers and small- and medium-sized enterprises. 


\section{References}

Allmendinger, G. and R. Lombreglia (2005). Four strategies for the age of smart services. Harvard Business Review, 83(10): 131-145.

Andrews, K. (1971). The Concept of Corporate Strategy. Homewood: Irwin, (Chapters 1-5).

Antioco, M., R. Moenaert, A. Lindgreen, and M. Wetzels (2008). Organizational antecedents to and consequences of service business orientations in manufacturing companies. Journal of the Academy of Marketing Science, 36: 337-358.

Auguste, B., E. Harmon, and V. Pandit, (2006). The right service strategies for product companies. The McKinsey Quarterly, 1: 40-51.

Baveja, S., J. Gilbert, and D. Ledingham, (2004), From products to services: why it's not so simple, Harvard Management Update, 9(4): 3-5.

Bryman, A. (2008). Social Research Methods, (3 ${ }^{\text {rd }}$ ed.). New York: Oxford University Press.

Catell, R. (1966). The scree test for number of factors, Multivariate Behavioral Research, 1: 245-276.

Chisnall, P. (2005). Marketing research, ( $7^{\text {th }}$ ed.). New York: McGraw-Hill International.

Churchill, G. (1979). A paradigm for developing better measures of marketing constructs. Journal of Marketing Research, XVI: 64-73.

Churchill, G. and D. Iacobucci (2005). Marketing research: Methodological foundations (9th ed.). Mason, Ohio: South-Western.

Copulsky, J. and M. Wolf (1990). Relationship marketing: positioning for the future. Journal of Business Strategy, 11(4): 16-20.

Davies, A., T. Brady, and M. Hobday (2006). Charting a path towards integrated solutions. MIT Sloan Management Review, 47(3): 39-48. 
Davies, A., T. Brady, and M. Hobday (2007). Organizing for solutions: system seller vs. systems integrator, Industrial Marketing Management, 36(2): 183-193.

de Vaus, D. (2002). Surveys in Social Research, (5th ed.). St. Leonards, NSW: Allen and Unwin.

DeVellis, R. (2003). Scale Development. Theory and Applications, (2nd ed.). Thousand Oaks: Sage.

Dillman, D. (2007). Mail and internet surveys. The tailored design method (2nd ed.). Hoboken, NJ: Wiley.

Eggert, A., J. Hogreve, W. Ulaga, and E. Muenkhoff (2011). Industrial services, product innovations, and firm profitability: a multiple-group latent growth curve analysis. Industrial Marketing Management, 40(5): 661-670.

Fang, E., R. Palmatier, and J. Steenkamp (2008). Effect of service transition strategies on firm value. Journal of Marketing, 72(4): 1-14.

Ferreira, F., J. Proença, R. Spencer, and B. Cova (2013). The transition from products to solutions: External business model fit and dynamics. Industrial Marketing Management, In press. Available at: http://dx.doi.org/10.1016/j.indmarman.2013.07.010 (accessed 4th October 2013).

Field, A. (2010). Discovering Statistics Using SPSS, (3rd ed.). Thousand Oaks: Sage.

Fowler, F. (2009). Survey Research Methods (4 ${ }^{\text {th }}$ ed.). Thousand Oaks: Sage.

Frambach, R., I. Wels-Lips, and A. Gundlach (1997). Proactive product service strategies; an application in the European health market. Industrial Marketing Management, 26(4): 341-352.

Frohlich, M. and R. Dixon (2001). A taxonomy of manufacturing strategies revisited, Journal of Operations Management, 19: 541-558. 
Gebauer, H. (2007). An investigation of antecedents for the development of customer support services in manufacturing companies. Journal of Business-to-Business Marketing, 14 (3): 59-96.

Gebauer, H. (2008). Identifying service strategies in product manufacturing companies by exploring environment-strategy configurations. Industrial Marketing Management, 37(3): 278-291.

Gebauer, H., E. Fleisch, and T. Friedli. (2005). Overcoming the service paradox in manufacturing companies. European Management Journal, 23(1), 14-26.

Gebauer, H. and C. Kowalkowski (2012), Customer-focused and service-focused orientation in organizational structures, Journal of Business and Industrial Marketing, 26(7): 527537.

Govindarajan, V. (1989). Implementing competitive strategies at the business unit level: implications of matching managers to strategies. Strategic Management Journal, 10(3): 251-269.

Griffin, A. and A. Page (1993). An interim report on measuring product development success and failure, Journal of Product Innovation Management, 10: 291-308.

Grönroos, C. (2000). Service Management and Marketing: A Customer Relationship Management Approach (2nd ed.). Chichester: Wiley.

Grönroos, C., and P. Helle. (2010). Adopting a service logic in manufacturing. Conceptual foundation and metrics for mutual value creation. Journal of Service Management, 21(5): 564-590.

Hair, J., W. Black, B. Babin, R. Anderson, and R. Tatham. (2006). Multivariate Data Analysis, (6th ed.). Upper Saddle River, NJ: Pearson Prentice Hall.

Helander, A. and K. Möller (2008). How to become a solution provider: system supplier's strategic tools, Journal of Business-to-Business Marketing, 15(3): 247-289. 
Homburg, C., M. Fassnacht, and C. Guenther (2003). The role of soft factors in implementing a service-orientated strategy in industrial marketing companies. Journal of Business-toBusiness Marketing, 10(2): 23-51.

Jacob, F. and W. Ulaga (2008). The transition from product to service in business markets: an agenda for academic inquiry. Industrial Marketing Management, 37(3): 247-253.

Ketchen, D. and C. Snook (1996). The application of cluster analysis in strategic management research. Strategic Management Journal, 17(6): 441-458.

Kowalkowski, C., D. Kindström, T.B. Alejandro, S. Brege, and S. Biggemann. (2012). Service infusion as agile incrementalism in action. Journal of Business Research, 65(6): 765-772.

Kowalkowski, C., D. Kindström, and P. Brehmer (2011). Managing industrial service offerings in global business markets. Journal of Business and Industrial Marketing, 26(3): 181-192.

Lay, G., G. Copani, A. Jäger, and S. Biege (2010). The relevance of service in European manufacturing industries. Journal of Service Management, 21(5): 715-726.

Lele, M. (1997). After-sales service - necessary evil or strategic opportunity? Managing Service Quality, 7(3): 141-145.

Lightfoot, H. and H. Gebauer (2011). Exploring the alignment between service strategy and service innovation. Journal of Service Management, 22(5): 664-683.

Lindell, M. and D. Whitney (2001). Accounting for common method variance in crosssectional research designs. Journal of Applied Psychology, 86(1): 114-121.

Mathieu, V. (2001a). Product services: from a service supporting the product to a service supporting the client, Journal of Business and Industrial Marketing, 16(1): 39-58.

Mathieu, V. (2001b). Service strategies within the manufacturing sector: benefits, costs and partnership. International Journal of Service Industry Management, 12(5): 451-475. 
Matthyssens, P. and K. Vandenbempt (2008). Moving from basic offerings to value-added solutions: strategies, barriers and alignment. Industrial Marketing Management, 37(3): 316-328.

Matthyssens, P. and K. Vandenbempt (2010). Service addition as business market strategy: identification of transition trajectories. Journal of Service Management, 21(5): 693-714.

Miller, J. and A. Roth (1994). A taxonomy of manufacturing strategies. Management Science, 40(3): 285-304.

Neely, A. (2009). Exploring the financial consequences of the servitization of manufacturing. Operations Management Research, 2(1): 103-118.

Neu, W. and S. Brown (2005). Forming successful business-to-business services in goodsdominated firms. Journal of Service Research, 8(1): 3-17.

Nordin, F. and C. Kowalkowski (2010). Solutions offerings: a critical review and reconceptualisation. Journal of Service Management, 21(4): 441-459.

Oliva, R., Gebauer, H., and Brann, J. M. (2012). Separate or Integrate? Assessing the impact of separation between product and service business on service performance in product manufacturing firms. Journal of Business-to-Business Marketing, 19(4): 309-334.

Oliva, R. and R. Kallenberg (2003). Managing the transition from product to services. International Journal of Service Industry Management, 14(2): 160-172.

Paiola, M., H. Gebauer, and B. Edvardsson (2012). Service business development in small- to medium-sized equipment manufacturers. Journal of Business-to-Business Marketing, 19(1): 33-66.

Parasuraman, A. (1998). Customer research in business-to-business markets: an agenda for research. The Journal of Business \& Industrial Marketing, 13(4/5): 309-321. 
Paxson, C. (1992). Follow-up mail surveys. Industrial Marketing Management, 21(3): 195201.

Penttinen, E. and J. Palmer (2007). Improving firm positioning through enhanced offerings and buyer-seller relationships. Industrial Marketing Management 36(5): 552-564.

Podsakoff, P., S. MacKenzie, J-Y. Lee, and N. Podsakoff (2003). Common method biases in behavioral research: a critical review of the literature and recommended remedies. Journal of Applied Psychology, 88(5): 879-903.

Porter, M. (1998). Competitive advantage. Creating and sustaining superior performance, (Export ed.) London: Free Press.

Punj, G. and D. Stewart (1983). Cluster analysis in marketing research: review and suggestions for application. Journal of Marketing Research, 20(2): 134-148.

Raddats, C. (2011). Aligning industrial services with strategies and sources of differentiation. Journal of Business and Industrial Marketing, 25(5): 332-343.

Raddats, C. and J. Burton (2011) Strategy and structure configurations within product-centric businesses. Journal of Service Management, 22(4): 160-172.

Raddats, C. and C. Easingwood (2010). Services growth options for B2B product-centric businesses. Industrial Marketing Management, 39(8): 1334-1345.

Robinson, T., C. Clarke-Hill, and R. Clarkson (2002). Differentiation through service: a perspective from the commodity chemical industry. The Service Industries Journal, 22(3): 149-166.

Salonen, A. (2011). Service transition strategies of industrial manufacturers. Industrial Marketing Management, 40(5): 683-690.

Saunders, M., P. Lewis, and A. Thornhill (2007). Research methods for business students (4th ed.). Harlow, England: Pearson Education, (Chapter 10). 
Sawhney, M., S. Balasubramanium, and V. Krishnan (2004). Creating growth with services. MIT Sloan Management Review, 45(2): 34-43.

Storbacka, K. (2011). A solution business model: capabilities and management practices. Industrial Marketing Management, 40(5): 699-711.

Stremersch, S., S. Wuyts, and R. Frambach (2001). The purchasing of full-service contracts: an exploratory study within the industrial maintenance market. Industrial Marketing Management, 30(1): 1-12.

Ulaga, W. and W. Reinartz (2011). Hybrid offerings: How manufacturing firms combine goods and services successfully. Journal of Marketing, 75(6): 5-23.

UK Standard Industrial Classification (SIC) of Economic Activities (2003), available at: http://www.businessballs.com/industrialclassifications.htm (accessed November 14th 2012).

Vandermerwe, S. and J. Rada (1988). Servitization of business: adding value by adding services. European Management Journal, 6(4): 314-324.

Vargo, S. and R. Lusch (2008). From goods to service(s): divergences and convergences of logics. Industrial Marketing Management, 37(3): 254-259.

Windahl, C. and N. Lakemond (2010). Integrating solutions from a service-centred perspective: applicability and limitations in the capital goods industry. Industrial Marketing Management, 39(8): 1278-1290.

Wise, R. and P. Baumgartner (1999). Go downstream: the new profit imperative in manufacturing. Harvard Business Review, 77(5): 133-141.

Wouters, J. (2004). Customer service strategy options: a multiple case study in a B2B setting. Industrial Marketing Management, 33(7): 583-592. 


\section{Implications for Business Marketing Practice}

Service infusion has become a key opportunity and challenge for many business-to-business (B2B) manufacturers over recent years, as they seek to develop more compelling customer offerings. Some manufacturers have developed after-sales service offerings to enhance the reliability of their own products; for example, spares and repair, technical support and customer training. Other manufacturers' service infusion approaches are less focused on product reliability and more focused on revenue growth; for example, outsourcing services, whereby the risk and responsibility for customers' operational processes is assumed by the manufacturer. Some manufacturers are even developing solutions; selling integrated product and service offerings to address important customer problems and being compensated on the basis of achieved performance. Despite the importance of services to many manufacturers some have not greatly developed their service offerings. To successfully infuse services manufacturers therefore need to align their strategies to their capabilities and market opportunities, with the three strategies set out in this paper providing a realistic appraisal of the roles services can take within manufacturing businesses.

To gain further insights into the distinction between manufacturers' service strategies and offerings, we conducted a survey of 145 B2B manufacturers from 14 industry sectors in the United Kingdom. This study therefore provides managers with findings that are applicable across all manufacturing sectors, rather than focusing on the sub-set of the manufacturing population for whom service infusion is an established business practice. Using factor and cluster analysis, the study finds support for the importance of making a clear distinction between service strategy and category of service offerings, the former being based on the latter. Previous research delineates a manufacturer's service offerings according to two 
primary dimensions; firstly, whether services are closely linked to products or activities in the customer's operational environment; secondly, whether services are specifically linked to own products or multi-vendor products, which will also include own products in most cases. An understanding of these primary dimensions should enable managers to better assess and categorize their service portfolios. From these two dimensions three categories of service offering were identified; product-attached services (e.g. product installation for own or multivendor products), operations services on own products (e.g. offering own products on an availability basis) and vendor independent operations services (e.g. offering multi-vendor products on an availability basis). In this context, a product's availability is the period of time that the product will be available for the customer to use, with issues such as maintenance and repair being the responsibility of the supplier and not charged for independently of the availability contract.

These service categories are used to specify three generic service strategies: Services Doubters, for whom services are not a strong differentiator with no focus on any category of service offerings; Services Pragmatists, for whom product-attached services are a key differentiator; Services Enthusiasts, for whom services are both a product differentiator and an enabler of growth, with all three categories of service offerings important. This means that only in one case (Services Pragmatist) does service strategy correspond to one category of service offerings (product-attached services). For the other two distinct service strategies it is not possible to delineate such equivalence. This means that managers should try to avoid categorizing their service strategy according to their service offerings, with a strategy often determined by other factors such as capabilities and market opportunities. Regarding industry sectors, there are major differences in terms of which service strategies manufacturers pursue; for example, more highly infused strategies were prevalent in the office machinery and 
computer sector, whereas less infused strategies are more prevalent in the basic metals and machinery sectors. Prior studies ascribe these differences to factors such as heterogeneity in customer demand, degree of deregulation and outsourcing, product complexity and role of intermediaries. These differences need to be recognized since differences between sectors may constrain what services strategies can be successfully pursued.

For some manufacturers (Services Doubters) service infusion is unlikely to be an appropriate approach to creating differentiation, with services either not valued by customers or products not amenable to service additions. For example, company A from this study manufactures materials for the construction industry. Whilst the company offers some services, such as providing logistics support to customers, its products are not generally amenable to extensive service additions. In this case differentiation should be sought through other means such as product innovation, customer centricity or cost leadership. Even if customers do value services, and products are amenable to service additions, manufacturers may still fail at implementing the strategy and not be able to take advantage of the strategic linkages between their product and service businesses. In this case manufacturers might need to undertake more long-term changes or extensive reconfigurations to ensure that they have the managerial attention, resources, capabilities, organizational structures and processes needed to benefit from services. Managers should be aware that building up a successful, large-scale service business is generally an incremental, non-linear process spanning several years or even decades.

For other manufacturers (Services Pragmatists) services play a crucial role in creating product differentiation, although it is possible that product-attached services could also be provided on other OEMs' products if customer demand dictates, and the products in question do not 
directly compete against a manufacturer's own. For example, company B from this study manufactures vehicles for the construction industry. Services agreements which include maintenance and repair of its vehicles are a key differentiator for the company. This strategy might be the limit to what services can achieve for these companies, since switching the focus away from product differentiation to facilitating services-led growth represents a fundamental realignment of a manufacturer's strategy, as well as potentially its organizational structure and capabilities. Thus, unless there are major external stimuli; for example, new customer demands for services, competition from low-cost providers of product-attached services or systems integrators threatening to become potential intermediaries between the manufacturer and its customers, changes in these manufacturers' service strategies are unlikely.

The final group of manufacturers (Services Enthusiasts) use services to both differentiate their own products and also develop services-led growth. For example, company $\mathrm{C}$ from this study manufactures telecommunications equipment and provides product-attached services related to its own equipment, but also an extensive range of vendor-independent services supporting customers in a range of operational activities. By positioning their services into 'defensive' (e.g. technical support) and 'offensive' (e.g. multi-vendor solution provision) offerings, Services Enthusiasts can pursue different approaches to service infusion at the same time. In order to be able to pursue variable approaches in practice manufacturers may need separate organizations for defensive and offensive service offerings. However, it should be noted that using services as both defensive and offensive manoeuvres can cause difficulties for an organization. As a defensive manoeuvre services are designed to help differentiate own products, whilst as an offensive manoeuvre services may embrace products from other OEMs, which might include those from competitors. Balancing these apparently contradictory positions is a complex and challenging activity, with services involving 
competitor products potentially undermining the role of services as a differentiating factor on own products. Service infusion is likely to remain one of the primary approaches that manufacturers can use to create sustainable competitive advantage. However, whilst being a Service Enthusiast is often portrayed as the ultimate goal of service infusion, we caution managers that it is not necessarily a panacea for growth. Our findings suggest that manufacturers need to have service strategies which best reflect their capabilities and the opportunities that their markets present, which in some cases may not be based on service infusion at all. 
Figure 1 - Framework of service categories (adapted from Raddats and Easingwood, 2010, p. 1338).

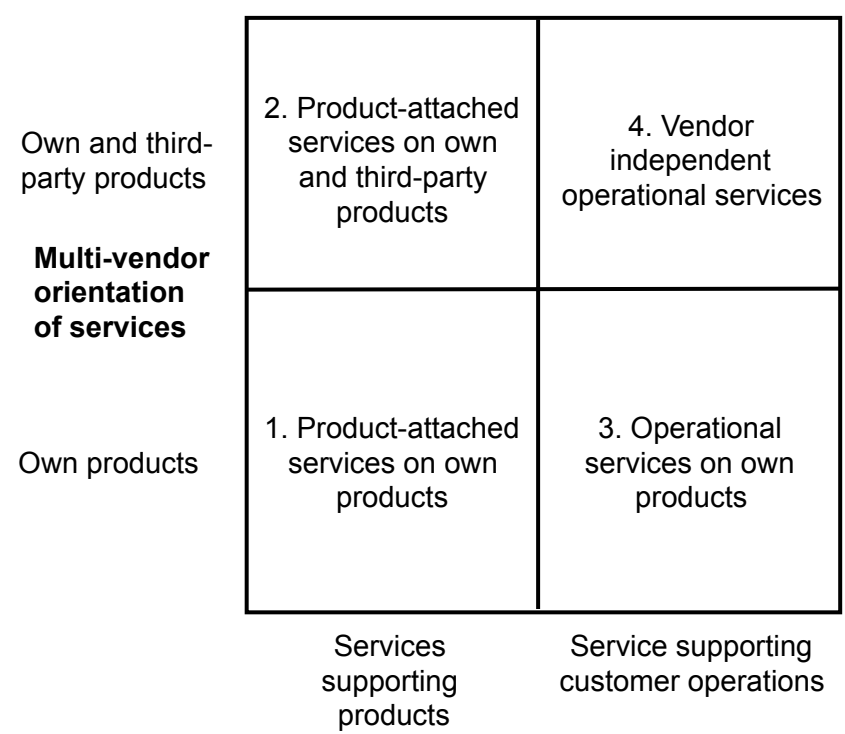

Product/customer orientation of services

Figure 2 - Service strategy typology

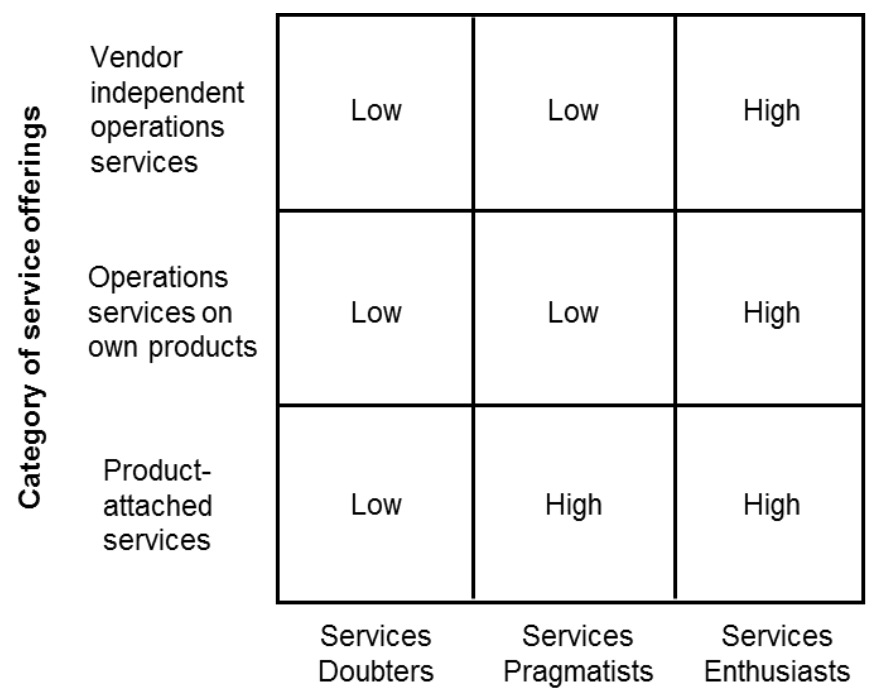

Service strategy

Note: 'High'/'Low' indicates the likelihood that a firm pursuing a particular strategy is offering a particular category of offerings 
Table 1 - Items used in the study

\begin{tabular}{|c|c|c|}
\hline Item & $\begin{array}{l}\text { Service } \\
\text { category } \\
\text { (Fig. 1) }\end{array}$ & $\begin{array}{l}\text { Rationale for item (other papers which } \\
\text { influenced the development of the item) }\end{array}$ \\
\hline $\begin{array}{l}\text { Our services are developed in } \\
\text { close cooperation with our } \\
\text { product businesses }\end{array}$ & 1 & $\begin{array}{l}\text { Services are strongly linked to a company's own } \\
\text { products. They are not specifically linked to } \\
\text { activities in the customer's operational environment } \\
\text { (Mathieu 2001a) }\end{array}$ \\
\hline $\begin{array}{l}\text { My company has created } \\
\text { services in standard modules } \\
\text { reflecting the requirements } \\
\text { of the products we supply }\end{array}$ & $1 / 2$ & $\begin{array}{l}\text { Services are created in modules which closely match } \\
\text { the needs of the products (own or OEM). Services } \\
\text { are not customized to customers' operational } \\
\text { requirements (Gebauer 2008) }\end{array}$ \\
\hline $\begin{array}{l}\text { The financial performance of } \\
\text { our services is closely aligned } \\
\text { to that of the products we } \\
\text { supply }\end{array}$ & $1 / 2$ & $\begin{array}{l}\text { As a company sells more products (own or OEM) it } \\
\text { also sells more services directly linked to the supply, } \\
\text { installation and support of these products (Auguste } \\
\text { et al. 2006) }\end{array}$ \\
\hline $\begin{array}{l}\text { Our services are developed in } \\
\text { close cooperation with the } \\
\text { original equipment } \\
\text { manufacturers (OEMs) of the } \\
\text { products we supply }\end{array}$ & 2 & $\begin{array}{l}\text { Services are strongly linked to OEMs' products. } \\
\text { They are not specifically linked to activities in the } \\
\text { customer's operational environment (Mathieu } \\
\text { 2001a) }\end{array}$ \\
\hline $\begin{array}{l}\text { Service contracts on our } \\
\text { products are designed on a } \\
\text { 'risk and reward' basis so that } \\
\text { customers pay us depending } \\
\text { upon the impact on } \\
\text { operational performance }\end{array}$ & 3 & $\begin{array}{l}\text { Services are not charged on a 'fixed fee' but instead } \\
\text { based on the manufacturer's operational } \\
\text { performance when delivering the services (Windahl } \\
\text { and Lakemond 2010) }\end{array}$ \\
\hline $\begin{array}{l}\text { My company offers our } \\
\text { products on an availability } \\
\text { basis }\end{array}$ & 3 & $\begin{array}{l}\text { Availability contracts show that many of the } \\
\text { operational activities/risks of service delivery for } \\
\text { own products have been assumed by the } \\
\text { manufacturer (Windahl and Lakemond 2010) }\end{array}$ \\
\hline $\begin{array}{l}\text { My company has taken over } \\
\text { the operational functions of } \\
\text { our products in customers' } \\
\text { businesses }\end{array}$ & 3 & $\begin{array}{l}\text { Products are no longer just supplied and supported, } \\
\text { but rather operated as well (Davies et al. 2006; } \\
\text { Gebauer 2008) }\end{array}$ \\
\hline $\begin{array}{l}\text { My company offers } \\
\text { consultancy on issues not } \\
\text { directly related to the products } \\
\text { we supply }\end{array}$ & 4 & $\begin{array}{l}\text { Offering non-product related consultancy indicates } \\
\text { that a manufacturer's services are independent of its } \\
\text { products (Auguste et al. 2006; Mathieu 2001a) }\end{array}$ \\
\hline $\begin{array}{l}\text { My company offers systems } \\
\text { integration of multi-vendor } \\
\text { projects }\end{array}$ & 4 & $\begin{array}{l}\text { Systems integration means combing products from } \\
\text { multiple vendors into a working system, indicating } \\
\text { product independence (Davies et al. 2006) }\end{array}$ \\
\hline $\begin{array}{l}\text { My company offers multi- } \\
\text { vendor products on an } \\
\text { availability basis }\end{array}$ & 4 & $\begin{array}{l}\text { Availability contracts provide an indication that } \\
\text { many of the operational activities/risks of service } \\
\text { delivery for multi-vendor products have been } \\
\text { assumed by the manufacturer (Davies et al. } 2006 \text {; }\end{array}$ \\
\hline
\end{tabular}




\begin{tabular}{|c|c|c|}
\hline & & Windahl and Lakemond 2010) \\
\hline $\begin{array}{l}\text { My company has taken over } \\
\text { some of our customers' } \\
\text { business processes }\end{array}$ & 4 & $\begin{array}{l}\text { Outsourcing business processes, rather than product } \\
\text { operations, indicates a high level of product } \\
\text { independence (Neely 2009) }\end{array}$ \\
\hline
\end{tabular}

Table 2 - Sector information for the population and completed sample

\begin{tabular}{|c|c|c|c|c|}
\hline \multirow[t]{2}{*}{ Sector (SIC [2003] code) } & \multicolumn{2}{|c|}{ Population } & \multicolumn{2}{|c|}{ Completed sample } \\
\hline & Number & Percentage & Number & Percentage \\
\hline Mining, extraction, printing $(10-14 ; 20-23)$ & 2127 & 21.8 & 7 & 4.5 \\
\hline $\begin{array}{l}\text { Manufacture of chemicals and chemical } \\
\text { products (24) }\end{array}$ & 907 & 9.3 & 11 & 7.1 \\
\hline $\begin{array}{l}\text { Manufacture of rubber and plastic products } \\
(25)\end{array}$ & 636 & 6.5 & 5 & 3.2 \\
\hline $\begin{array}{l}\text { Manufacture of other non-metallic mineral } \\
\text { products }(26)\end{array}$ & 309 & 3.2 & 3 & 1.9 \\
\hline Manufacture of basic metals (27) & 326 & 3.3 & 4 & 2.6 \\
\hline $\begin{array}{l}\text { Manufacture of fabricated metal products } \\
(28)\end{array}$ & 1381 & 14.1 & 21 & 14.5 \\
\hline $\begin{array}{l}\text { Manufacture of machinery and equipment } \\
\text { not elsewhere classified (29) }\end{array}$ & 928 & 9.5 & 24 & 16.6 \\
\hline $\begin{array}{l}\text { Manufacture of office machinery and } \\
\text { computers (30) }\end{array}$ & 149 & 1.5 & 14 & 9.7 \\
\hline $\begin{array}{l}\text { Manufacture of electrical machinery and } \\
\text { apparatus (31) }\end{array}$ & 608 & 6.2 & 9 & 5.8 \\
\hline $\begin{array}{l}\text { Manufacture of radio, TV and } \\
\text { communication equipment (32) }\end{array}$ & 315 & 3.2 & 11 & 7.1 \\
\hline $\begin{array}{l}\text { Manufacture of medical, precision and } \\
\text { optical instruments (33) }\end{array}$ & 433 & 4.4 & 9 & 6.2 \\
\hline Manufacture of motor vehicles (34) & 296 & 3.0 & 2 & 1.3 \\
\hline $\begin{array}{l}\text { Manufacture of other transport equipment } \\
\text { (35) }\end{array}$ & 270 & 2.8 & 8 & 5.2 \\
\hline Other manufacturing (36) & 1082 & 11.1 & 17 & 11.7 \\
\hline TOTAL & 9769 & 100 & 145 & 100 \\
\hline
\end{tabular}


Table 3 - Results of exploratory factor analysis

\begin{tabular}{|c|c|c|}
\hline $\begin{array}{l}\text { Factor (category of service offerings) and } \\
\text { associated items }\end{array}$ & Factor loading & Cronbach Alpha \\
\hline Product-attached services & & .7 \\
\hline $\begin{array}{l}\text { Our services are developed in close cooperation } \\
\text { with our product businesses }\end{array}$ & .78 & \\
\hline $\begin{array}{l}\text { My company has created services in standard } \\
\text { modules reflecting the requirements of the products } \\
\text { we supply }\end{array}$ & .51 & \\
\hline $\begin{array}{l}\text { The financial performance of our services is closely } \\
\text { aligned to that of the products we supply }\end{array}$ & .57 & \\
\hline $\begin{array}{l}\text { Our services are developed in close cooperation } \\
\text { with the original equipment manufacturers (OEMs) } \\
\text { of the products we supply }\end{array}$ & .7 & \\
\hline Operations services on own products & & .7 \\
\hline $\begin{array}{l}\text { Service contracts on our products are designed on a } \\
\text { 'risk and reward' basis so that customers pay us } \\
\text { depending upon the impact on operational } \\
\text { performance }\end{array}$ & .72 & \\
\hline $\begin{array}{l}\text { My company offers our products on an availability } \\
\text { basis }\end{array}$ & .86 & \\
\hline $\begin{array}{l}\text { My company has taken over the operational } \\
\text { functions of our products in customers' businesses }\end{array}$ & .61 & \\
\hline Vendor independent operations services & & .71 \\
\hline $\begin{array}{l}\text { My company offers consultancy on issues not } \\
\text { directly related to the products we supply }\end{array}$ & .75 & \\
\hline $\begin{array}{l}\text { My company offers systems integration of multi- } \\
\text { vendor projects }\end{array}$ & .79 & \\
\hline $\begin{array}{l}\text { My company offers multi-vendor products on an } \\
\text { availability basis }\end{array}$ & .58 & \\
\hline $\begin{array}{l}\text { My company has taken over some of our } \\
\text { customers' business processes }\end{array}$ & .53 & \\
\hline
\end{tabular}

Table 4 - ANOVA tests associated with cluster analysis

\begin{tabular}{|l|l|l|}
\hline Factor & $\boldsymbol{F}$-test & $\boldsymbol{p}$-value \\
\hline Product-attached services & 29.38 & 0.00 \\
\hline Operations services on own products & 58.34 & 0.00 \\
\hline Vendor independent operations services & 151.16 & 0.00 \\
\hline
\end{tabular}


Table 5 - Cluster means for each factor $(n=145)$

\begin{tabular}{|l|l|l|l|}
\hline Factor & $\begin{array}{l}\text { Cluster 1 } \\
(\mathbf{n = 6 5})\end{array}$ & $\begin{array}{l}\text { Cluster 2 } \\
(\mathbf{n}=\mathbf{2 6})\end{array}$ & $\begin{array}{l}\text { Cluster 3 } \\
(\mathbf{n}=\mathbf{5 4})\end{array}$ \\
\hline $\begin{array}{l}\text { Product-attached services } \\
\text { (maximum value 28) }\end{array}$ & 19.4 & $12.9 *$ & 19.9 \\
\hline $\begin{array}{l}\text { Operations services on own products } \\
\text { (maximum value 21) }\end{array}$ & $13.6^{*}$ & 6.8 & 7.8 \\
\hline $\begin{array}{l}\text { Vendor independent operations services } \\
\text { (maximum value 28) }\end{array}$ & $20.5 *$ & 10 & 9.8 \\
\hline
\end{tabular}

* Significant differences $(p<.05)$ between this cluster and others for each factor

Table 6 - Cluster differences identified through discriminating variables $(n=145)$

\begin{tabular}{|l|l|l|l|l|}
\hline Variable & Variable & Cluster 1 & Cluster 2 & Cluster 3 \\
mean & $(\mathbf{n = 6 5 )}$ & $(\mathbf{n = 2 6})$ & (n = 54) \\
\hline Percentage of your company's turnover & 2.0 & $2.4^{*}$ & 1.8 & 1.7 \\
\hline Products provide my company with & 5.4 & 5.1 & 5.5 & $5.8 *$ \\
sustainable competitive advantage & & & & \\
\hline Services are a stand-alone business & 3.8 & $4.3 *$ & 4.0 & 3.2 \\
within my company's organisation & & & & \\
\hline
\end{tabular}

* The dominant cluster for this variable. Each variable discriminates cluster membership $(\mathrm{p}<$ $.05)$ 